\title{
FERTILIZATION AND SOIL AERATION EFFECTS ON GRASSLAND PRIMARY PRODUCTIVITY AND SPECIES DIVERSITY IN A MEADOW STEPPE, NORTHERN CHINA
}

\author{
BAI, Y. $.^{1,2 \#}-$ LV, S. ${ }^{1 \#}-$ SCHELLENBERG, M. P. ${ }^{2}-$ YAN, R. ${ }^{3}-$ ZHANG, R. ${ }^{1,2}-$ WIE, Z. $^{1 *}$ \\ ${ }^{1}$ College of Grassland, Resources and Environment, Key Lab. of Grassland Resources of the \\ Ministry of Education of China, Key Lab. of Forage Cultivation, Processing and High Efficient \\ Utilization of the Ministry of Agriculture of China, Inner Mongolia Agricultural Univ., No. 29 \\ Erdos Street, Hohhot, Inner Mongolia 010011, China
}
${ }^{2}$ Swift Current Research and Development Centre, Agriculture and Agri-Food Canada, 1 Airport Rd, Box 1030, Swift Current, Saskatchewan S9H 3X2, Canada

${ }^{3}$ Institute of Agricultural Resources and Regional Planning, Chinese Academy of Agricultural Sciences, Beijing 100081, China

${ }^{\#}$ These authors contributed equally to this study and share first authorship

*Corresponding author

e-mail: nmndwzj@163.com

(Received 22 $2^{\text {nd }}$ Dec 2019; accepted 23 $3^{\text {rd }}$ Mar 2020)

\begin{abstract}
In the grassland ecosystem, soils are subjected to a range of stresses which may affect their physical and biological properties, as well as the plant community biomass. As biomass is affected by long-term soil properties, we sought to establish a direct link between biomass and resilience to fertilization and soil aeration. We evaluated biomass yield in grasslands managed across a gradient of nitrogen $(\mathrm{N})$, phosphorus $(\mathrm{P})$, and potassium $(\mathrm{K})$ fertilizers at Hulunbuir in Inner Mongolia, China, from 2014 to 2017. Based on the estimates from the simulated optimization and optimal theoretical regression model, we recommend applying $\mathrm{N}\left(231.50-238.82 \mathrm{~kg} \mathrm{ha}^{-1}\right)$, and $\mathrm{P}\left(187.25-218.75 \mathrm{~kg} \mathrm{ha}^{-1}\right)$, and $\mathrm{K}(28.28-$ $33.32 \mathrm{~kg} \mathrm{ha}^{-1}$ ) annually to maximize biomass in the non-aerated grassland. The positive effect of nitrogen and phosphorus on biomass was significantly higher than unfertilized treatment. The effects of aeration on biomass were less explicit. Simultaneously, we compared the Shannon-Wiener Index and Species richness for the suitable fertilizer levels. Shannon-Wiener diversity and Species richness became lower the longer the fertilization treatments lasted. Thus, nutrient resorption is resulting in a decrease in species diversity and richness, while it is an important strategy for increasing plant biomass.
\end{abstract}

Keywords: nitrogen fertilizer, phosphorus fertilize, potassium fertilizer, soil improvement, community biomass, species diversity

\section{Introduction}

Temperate and semiarid grasslands comprise $80 \%$ of the land area on the Mongolian Plateau and environs, which includes Mongolia, and the province of Inner Mongolia, China (John et al., 2018). The increased degradation of Inner Mongolia steppe in recent years mainly occurred due to changes in the forms of land-use (Aguiar et al., 1996; Lambin and Meyfroidt, 2011). Long-term hay harvesting in Inner Mongolia Steppe through exportation of nutrients in the hay affects nutrient availability by decreasing soil $\mathrm{K}$ and $\mathrm{N}$ contents, and leading to significant changes in the above- and belowground components of the ecosystem (Bardgett et al., 1998; Kuzyakov et al., 1999; Olde Venterink et al., 2009). Fertilizers application is potentially key for the fast-growing species that typically establish in moderately fertile grasslands and during the early stages 
of restoration (Yahdjian et al., 2011). However, there are striking discrepancies in the fertilizer effect on productivity, which is largely due to the great variation in fertilizer type and concentration, soil fertility, amount of rainfall, temperature variations, and management practices (Gough et al., 2000; Hofer et al., 2017; Zhou et al., 2018). It is known that fertilization often decreases soil $\mathrm{pH}$ and that subsequent soil acidification has negative effects on plant communities (Basso et al., 2016; Liu et al., 2017). Therefore, determining the appropriate fertilizer type and concentration is essential for the sustainable management of ecosystems with nutrient additions.

Productivity and plant diversity are important indicators of grassland structure and function. The primary productivity of grasslands is the capability of their plant communities to convert carbon dioxide and water into energy-rich organic material (Yu et al., 2015). Nitrogen $(\mathrm{N})$, phosphorus $(\mathrm{P})$, and potassium $(\mathrm{K})$ are common nutrient elements constraining plant productivity in most grassland ecosystems. Their input often has multiple effects including changes in aboveground primary productivity, biodiversity, species composition, and ecosystem functioning (Bai et al., 2010; Li et al., 2010). Although the influence of $\mathrm{N}$ addition on grassland plant communities has been widely studied, it is still unclear whether observed patterns and underlying mechanisms are constant across biomes (Haque et al., 2009; Humbert et al., 2016; Long et al., 2016; Plassmann et al., 2009). The effects of $\mathrm{N}$ addition can alter plant community structure including plant productivity and plant diversity (Gough et al., 2000; Han et al., 2011; Plassmann et al., 2009). Some studies, however, have shown that the composition and proportion of the original plant community (i.e. grasses, forbs, legumes and sedges), can influence the direction and magnitude of the changes from $\mathrm{N}$ addition (Bai et al., 2010; Bassin et al., 2007; Tilman et al., 2001). Grasses are generally favoured by $\mathrm{N}$ addition, while legumes are not. Compared to nitrogen fertilizer, phosphorus fertilizer is beneficial to the growth of legumes. $\mathrm{P}$ is an essential macronutrient in plant nutrition and the second most important nutrient after $\mathrm{N}, 30-65 \%$ of which is present in organic forms (Harrison, 1983). Despite many soils containing a large amount of total $\mathrm{P}$, only a small proportion is available for plant uptake. Moreover, plant yield response to $\mathrm{P}$ fertilization can vary greatly (George et al., 2011; Schulte and Herlihy, 2007). Organic P in soil plays an important role in determining the overall biological availability of $\mathrm{P}$, and it is influenced by environment conditions, together with land use (Turner et al., 2003). Long-term $\mathrm{N}$ addition facilitates more $\mathrm{P}$ stored in organic forms, the prevalence of co-limitation by $\mathrm{N}$ and phosphorus (P) is increasingly recognized (Agren et al., 2012; Elser et al., 2007; Fay et al., 2015; Zhang and MacKenzie, 1997). K occurs in high concentrations in plant tissues and its uptake is correlated with that of other nutrients. $\mathrm{N}$ increases will potentially limit increases of other nutrients, such as $\mathrm{P}, \mathrm{K}$, or trace elements. Multiple-nutrient limitations of grassland productivity often occur in the form of co-limitation, while it is synergistic when the response to multiple nutrients is greater than the sum of the responses to each nutrient added individually. The collective effect of $\mathrm{N}, \mathrm{P}$ and $\mathrm{K}$ on grassland productivity and plant diversity are the focus of our attention.

In general, the grassland systems are rather stable compared to arable systems. However, the soil may be compacted due to deterioration inappropriate management system and weather impacts and their interaction (wheel traffic, drought, winter damages, flooding, slurry application, under- or overgrazing) (Kayser et al., 2018). Moreover, the vegetation of grassland in our study is dominated by Leymus chinensis (Trin.) Tzvel. Leymus chinensis a perennial rhizomatous grass. Development of rhizomes results in the decreased aeration resulting in decreased yield of Leymus 
chinensis over time. The intention of perforation on the soil is to bring grasslands back to the state of aeration which they once had (Franklin et al., 2006). Soil aeration may partially incorporate fertilizer applied to the soil, increase contact time between water, fertilizer, and soil to facilitate nutrient adsorption by the soil, and ideally even improve the swards by taking advantage of improvement in fertilization and soil aeration (Franklin et al., 2006). The objectives of this study were to: (1) determine the coupling effects of soil aeration and NPK fertilizer on aboveground net primary productivity, and (2) determine optimal options for improvement of grassland yield through the different combination of NPK fertilizer, and (3) compare the change trend of species richness and Shannon-Wiener Index of optimal fertilization levels in different years.

\section{Materials and methods}

\section{Study sites and experimental design}

The fertilization experiment was conducted near Hulunbuir Grassland Ecosystem National Field Observation Station, China (49.2313N, 120.0247E). The station, which was built in 1997 by the Chinese Academy of Agricultural Sciences, is located in the core area of Hulunbuir Meadow steppe. The average elevation of this area is 4320 m.a.s.l. The climate is continental semi-arid with a dry and cold winter and a rainy summer. The mean annual temperature is $0{ }^{\circ} \mathrm{C}$. The annual precipitation ranges from about 250-350 mm, of which about half falls between June and August. The frost-free period is 85 to 155 days. The type of soil is Kastanozem (FAO). The vegetation is dominated by Leymus chinensis (Trin.) Tzvel., Vicia amoena (Fisch. ex DC.), Thalictrum squarrosum (Steph.), Pulsatilla turczaninovii (Kryl. et Serg.), Stipa baicalensis (Roshev.), and Cleistogenes squarrosa (Trin.) Keng, and accompanied by Carex duriuscula (C. A. Mey.), Allium bidentatum (Allium L.), and Artemisia tanacetifolia (Linn.). Prior to 2014, the grassland was irregularly grazed by cattle and the site was hayed once a year in autumn.

In order to prevent grazing, the fertilization experiment was started at a number of permanent plots within an enclosure in 2013, along with the haying regime. The plots had similar plant community composition and structure before fertilizer addition. Fourteen, 6 $\mathrm{m} \times 10 \mathrm{~m}$, plots were randomly placed on the two soil mechanical treatments perforated or non-perforated respectively with an average separation distance of about $2 \mathrm{~m}$ in May 2014 (Fig. 1). The soil perforated by using mechanical with $12 \mathrm{~cm}$ depth and $15 \mathrm{~cm}$ distance between two holes, and only use it once before the experiment started (Fig. 2). An L14 $\left(3^{4}\right)$ orthogonal test was chosen to test their effects on the biomass of plant community and Leymus chinensis. The orthogonal test is an effective measurement to assay the comprehensive effect of multiple factors, finding the dominant factors and the best combination of levels for them with the least experimental trials, enhancing the reproducibility of the experimental results (Montgomery, 1991). The L14 $\left(3^{4}\right)$ orthogonal test for the experiment was to reduce workload, while it could arrange fourteen treatments with three factors and their four levels each, and test the interactions between factors if they exist. The local soil nutrient survey results in 2013 (total $\mathrm{N}$ content in $0 \sim 30 \mathrm{~cm}$ soil was $2.86 \mathrm{~g} \cdot \mathrm{kg}^{-1}$, the total $\mathrm{P}$ was $0.49 \mathrm{~g} \cdot \mathrm{kg}^{-1}$ and the total $\mathrm{K}$ was $22.96 \mathrm{~g} \cdot \mathrm{kg}^{-1}$ ) were used along with consideration of local traditional fertilization in selecting fourteen fertilizer treatments (T1 to T14) with $\mathrm{N}, \mathrm{P}$, and $\mathrm{K}$, and four fertilization concentrations for each fertilizer by artificial fertilization (Table 1). We mixed the fertilizer in advance, and 
spread fertilizer by artificial in late May. The perforated and non-perforated blocks with denoted as T1 (1) T14 (1) and T1 (2) T14 (2) respectively.

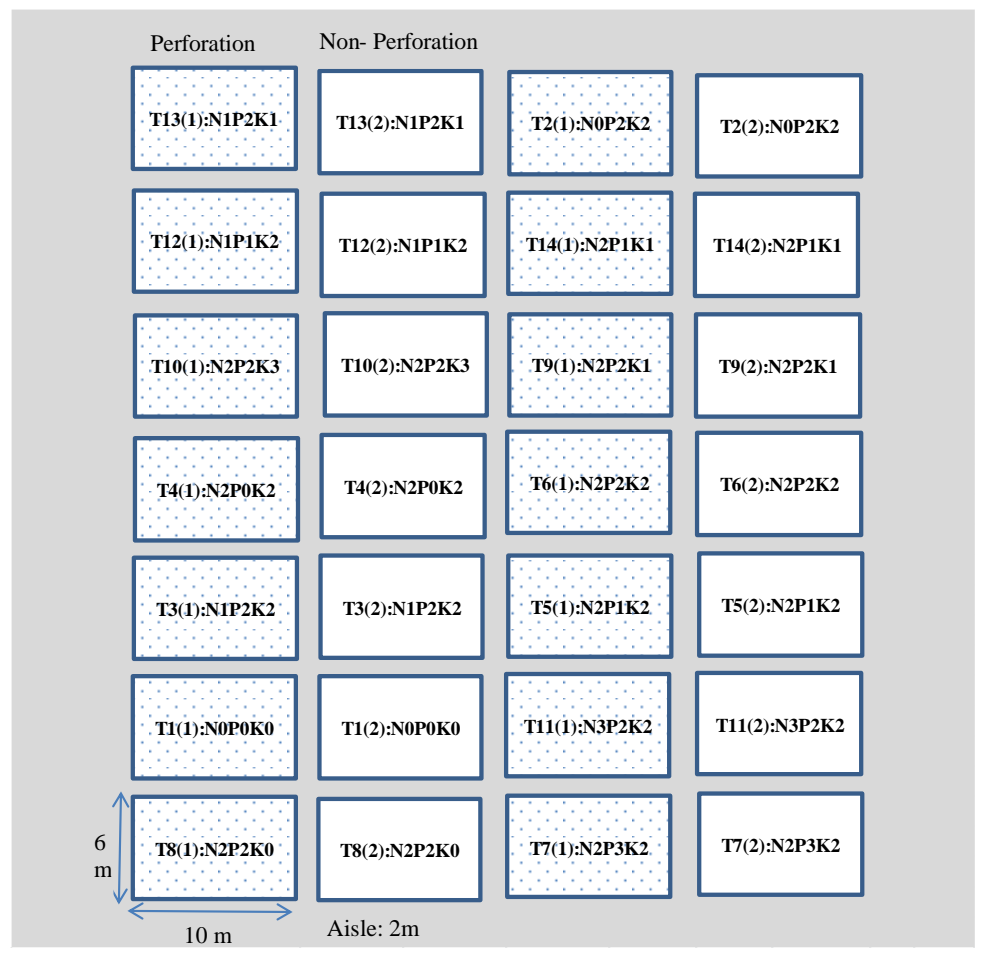

Figure 1. Map of the experimental site

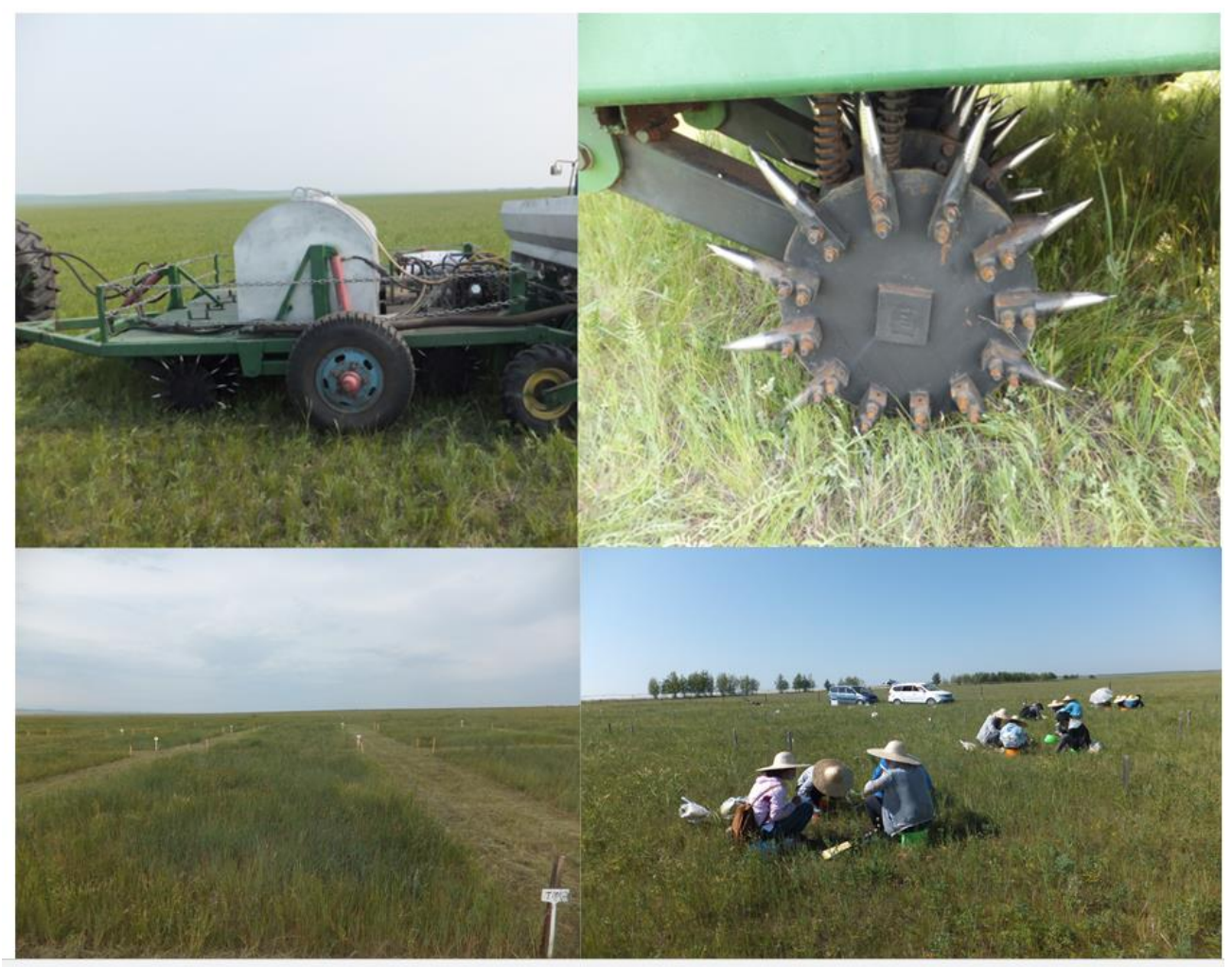

Figure 2. The photo of soil perforation equipment and taking sample 
Bai et al.: Fertilization and soil aeration effects on grassland primary productivity and species diversity in a Meadow Steppe, Northern China

-4543 -

Table 1. L14 $\left(3^{4}\right)$ orthogonal test for the combinational effect trial and fertilization amounts of nitrogen $(N)$, phosphorous $(P)$ and potassium $(K)$ applied

\begin{tabular}{c|c|c|c|c|c|c|c}
\hline \multirow{2}{*}{$\begin{array}{c}\text { Plot } \\
\text { number }\end{array}$} & \multirow{2}{*}{ Treatment } & \multicolumn{3}{|c|}{ Factors } & \multicolumn{3}{c}{ Fertilization amounts of $\mathbf{~}, \mathbf{P}, \mathbf{K}$} \\
\cline { 3 - 7 } & & $\mathbf{N}(\mathbf{X 1})$ & $\mathbf{P}(\mathbf{X 2})$ & $\mathbf{K}(\mathbf{X 3})$ & $\begin{array}{c}\mathbf{C O N}_{\mathbf{2}} \mathbf{H}_{4} \\
\left(\mathbf{k g ~ h a}^{-1}\right)\end{array}$ & $\begin{array}{c}\mathbf{C a P}_{2} \mathbf{H}_{4} \mathbf{O}_{\mathbf{8}} \\
\left(\mathbf{k g ~ h a}^{-1}\right)\end{array}$ & $\begin{array}{c}\mathbf{K}_{2} \mathbf{S O}_{4} \\
\left(\mathbf{k g ~ h a}^{-1}\right)\end{array}$ \\
\hline T1 & N0P0K0 & 0 & 0 & 0 & 0 & 0 & 0 \\
T2 & N0P2K2 & 0 & 2 & 2 & 0 & 350 & 57 \\
T3 & N1P2K2 & 1 & 2 & 2 & 91 & 350 & 57 \\
T4 & N2P0K2 & 2 & 0 & 2 & 183 & 0 & 57 \\
T5 & N2P1K2 & 2 & 1 & 2 & 183 & 175 & 57 \\
T6 & N2P2K2 & 2 & 2 & 2 & 183 & 350 & 57 \\
T7 & N2P3K2 & 2 & 3 & 2 & 183 & 525 & 57 \\
T8 & N2P2K0 & 2 & 2 & 0 & 183 & 350 & 0 \\
T9 & N2P2K1 & 2 & 2 & 1 & 183 & 350 & 28 \\
T10 & N2P2K3 & 2 & 2 & 3 & 183 & 350 & 85 \\
T11 & N3P2K2 & 3 & 2 & 2 & 274 & 350 & 57 \\
T12 & N1P1K2 & 1 & 1 & 2 & 91 & 175 & 57 \\
T13 & N1P2K1 & 1 & 2 & 1 & 91 & 350 & 28 \\
T14 & N2P1K1 & 2 & 1 & 1 & 183 & 175 & 28 \\
\hline
\end{tabular}

The Urea $(\mathrm{N} \geq 46.4 \%)$, Calcium superphosphate $\left(\mathrm{P}_{2} \mathrm{O}_{5} \geq 16 \%\right)$, Potassium sulfate $\left(\mathrm{K}_{2} \mathrm{O} \geq 51 \%\right)$ were applied for nitrogen fertilizer $(\mathrm{N})$, phosphate fertilizer $(\mathrm{P})$, and potassium fertilizer $(\mathrm{K})$ respectively with artificial fertilization

\section{Biomass sampling}

Except for surface litter, the total biomass of all plants was harvested from $0.5 \mathrm{~m} \times$ $0.5 \mathrm{~m}$ squares in August of each year between 2014 and 2017 with three repetitions randomly selected in each plot. Different species were separately cut to the ground level using scissors in each square area. All species were separately weighed after drying at $65^{\circ} \mathrm{C}$ for $24 \mathrm{~h}$ in the oven. The plant community biomass was the total of all plants biomass in each plot (Sala et al., 1988).

\section{Species diversity}

In each plot, we randomly selected three $0.25 \mathrm{~m}^{2}$ quadrats for the investigation of plant diversity. Every August was chosen to test because of the peak number of plant species biomass at this time. The richness was measured using number of species per square area. The diversity index was calculated using the Shannon-Wiener diversity index (Shannon, 1949).

\section{Statistical analysis}

\section{The analysis of mono-fertilizer}

Based on the design and character of the orthogonal experiment, the effect of the nitrogen fertilizer gradient on biomass in the perforated plots was analyzed using the same fertilizer gradient of phosphate fertilizer and potassium fertilizer. Nitrogen fertilizer was used as follows T1 (NOP0K0), T2 (NOP2K2), T3 (N1P2K2), T6 (N2P2K2), and T11 (N3P2K2); phosphate fertilizer was used as follows T1 (NOP0K0), 
T4 (N2P0K2), T5 (N2P1K2), T6 (N2P2K2), and T7 (N2P3K2); and potassium fertilizer was used as follows T1 (N0P0K0), T8 (N2P2K0), T9 (N2P2K1), T6 (N2P2K2), and T10 (N2P2K3). The method of non-perforated plots was the same. The average of no fertilizer (NOPOK0) and nitrogen-free fertilizer (NOP2K2) was used for the initial gradient of nitrogen fertilizer.

\section{The analysis of double-fertilizer effect}

The double-fertilizer effect of $\mathrm{N}$ and $\mathrm{P}$ was calculated using all the treatments which contained second gradient of $\mathrm{K}$ (T1 T7 and T11 T12), and nitrogen-free fertilizer (NOP2K2); the effect of $\mathrm{N}$ and $\mathrm{K}$ was calculated using all the treatments which contained second gradient of $\mathrm{P}$ (T1 T3, T6, T8 T11, and T13), and nitrogen-free fertilizer (NOP2K2); the effect of $\mathrm{P}$ and $\mathrm{K}$ was calculated using all the treatments which contained second gradient of $\mathrm{N}$ (T1, T4 T10, and T14), and nitrogen-free fertilizer (NOP2K2). The contour map with selected data above was drawn using SigmaPlot (Version 10.0).

\section{Full information model and simulation optimization}

The full information model is a comprehensive model, which contains to the linear effect, parabola effect, and interaction of independent variable. In our study, we use two full information to obtain the linear effect and parabola effect between the four years average biomass (Y) and nitrogen (X1), phosphorous (X2), and potassium (X3), as well as the interaction of dual-fertilizer. that specifies the relationship between a dependent biomass (Y) and nitrogen (X1), phosphorous (X2) and potassium (X3). Due to a field semi-control experiment with the fertilizer gradient, we believed the actual circumstances are reflected primarily by the regression model, and it was accepted that the liner positive correlation coefficient reached $75 \%$.

According to the full information model $(\mathrm{P}<0.15)$, the theoretical biomass was recalculated with the 0.2 step size and the code $0,1,2,3$ for the mono-fertilizer gradient. The 4096 samples data were available in the perforated and non-perforated plots respectively and the highest one in each plot were taken as the standard. Any greater than the value in each plot was considered to be the optimal values for the biomass. The theoretical range of optimal fertilization amount and biomass were obtained by using recalculating the optimal values.

\section{Optimal theoretical regression model}

The average biomass of four years in the in perforated and non-perforated plots were overall analyzed, a new stepwise regression model was obtained, to identify the key factors on biomass. The probability of variable introduction and rejection were all set to 0.15. All above statistical analyses were carried out with SAS 9.0 (SAS Institute Inc., Cary NC, USA).

\section{Results}

\section{Environmental conditions during the fertilization experiment}

During fertilization, the monthly averages of growing-season air temperature from May to August were similar in 2014-2017, but there was a great difference in rainfall (Fig. 3). The average of rainfall in 2014 growing-season was $82.28 \mathrm{~mm}, 78 \%, 114 \%$ 
and $108.03 \%$ higher than that in 2015, 2016 and 2017 respectively. Especially in June and July, the average of rainfall in 2014 was 3.58, 2.37 and 4.05 times more than that in 2015, 2016 and 2017.

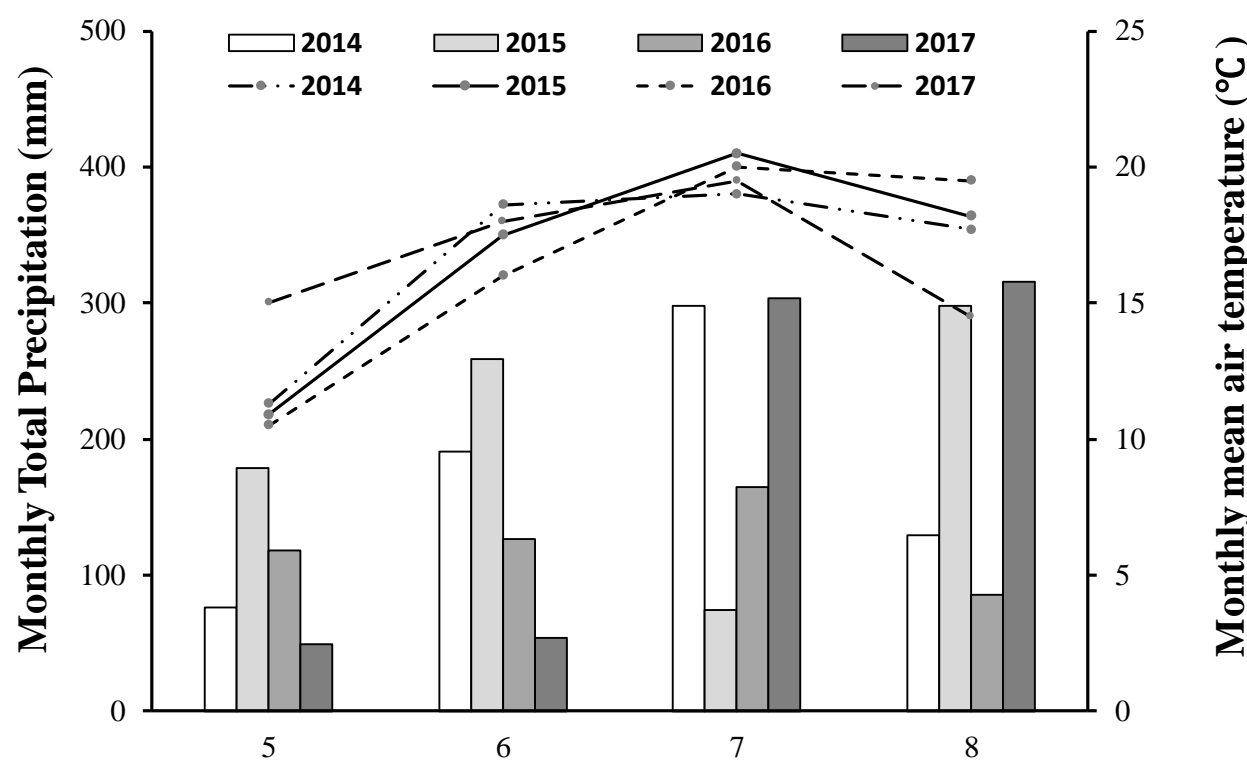

Month

Figure 3. Monthly (May to August) mean air temperature (lines) and rainfall (bars) received during the study period in 2014-2017 at the experiment site near Hulunbuir Grassland Ecosystem National Field Observation Station

\section{The effect of mono-nutrient}

The plant community biomass showed a clear response to the single fertilizer application (Fig. 4). The biomass in the perforated plots initially declined slowly with an increase of $\mathrm{P}$ and $\mathrm{K}$. Then beyond the second gradient, the biomass increased. The biomass improved continuously with an increase of N. Compared with perforated plots, the trend in non-perforated plots was completely opposite. The biomass increased with a slow decline of $\mathrm{P}$ and $\mathrm{K}$, but beyond a certain concentration, the biomass of $\mathrm{P}$ and $\mathrm{K}$ actually decreased: excess application of $\mathrm{P}$ and $\mathrm{K}$ reduced the plant community biomass in the non-perforated plots.

\section{The effect of binary fertilizer formulations}

The effect of binary formulations of NP and NK played a positive role in the increase of biomass in the perforated or non-perforated plots (Fig. 5). The differences for phosphate and potassium fertilizers were more complex for the PK combination. Notably, there is an interaction between nitrogen and potassium in the perforated area. This phenomenon was more pronounced in the effect of double-fertilizer of PK in the perforated plots. In the non-perforated plots, the biomass increased with the increase of the phosphorus and potassium fertilizer gradient. When $\mathrm{P}=2$ and $\mathrm{K}=1.5$, the highest biomass was achieved. The effect of double-fertilizer on biomass in the perforated plots and non-perforated plots were almost the similar (the contour line density and variation range represent the influence degree. 

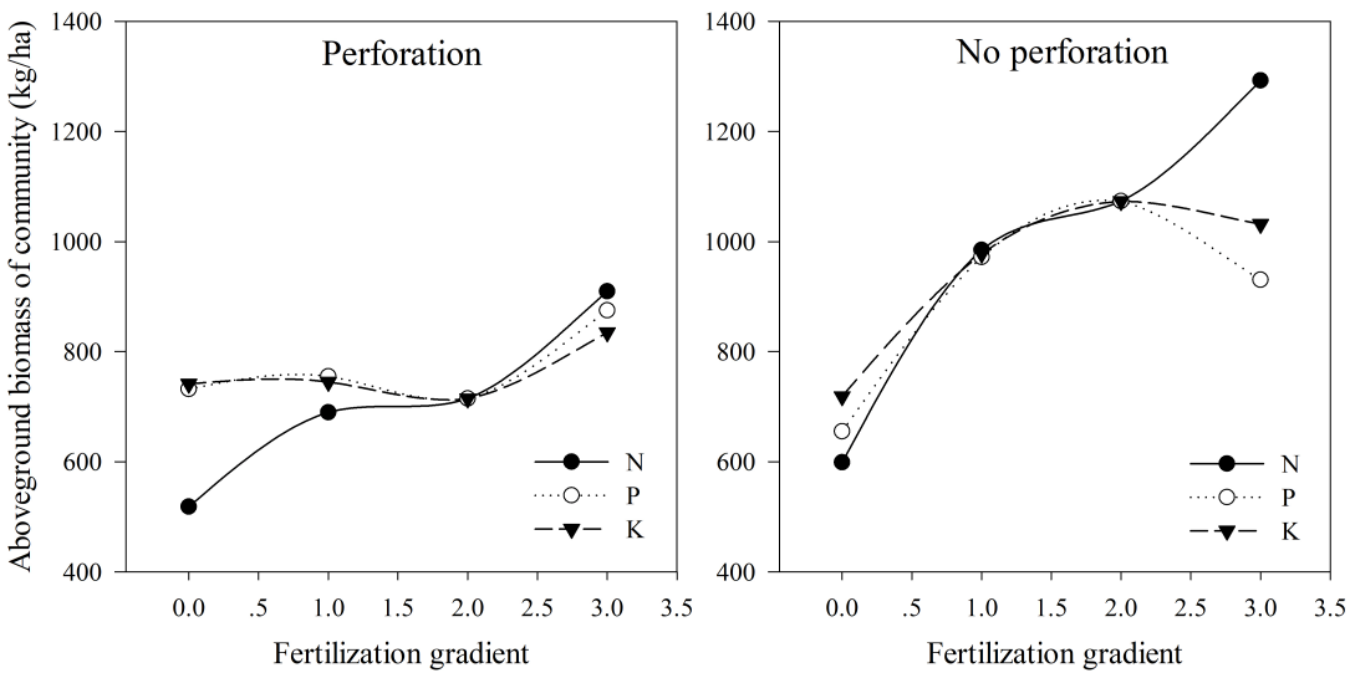

Figure 4. Mono-fertilizer effect on the plant community biomass from 2014 to 2017. The amount of each fertilizer were shown in Table 1
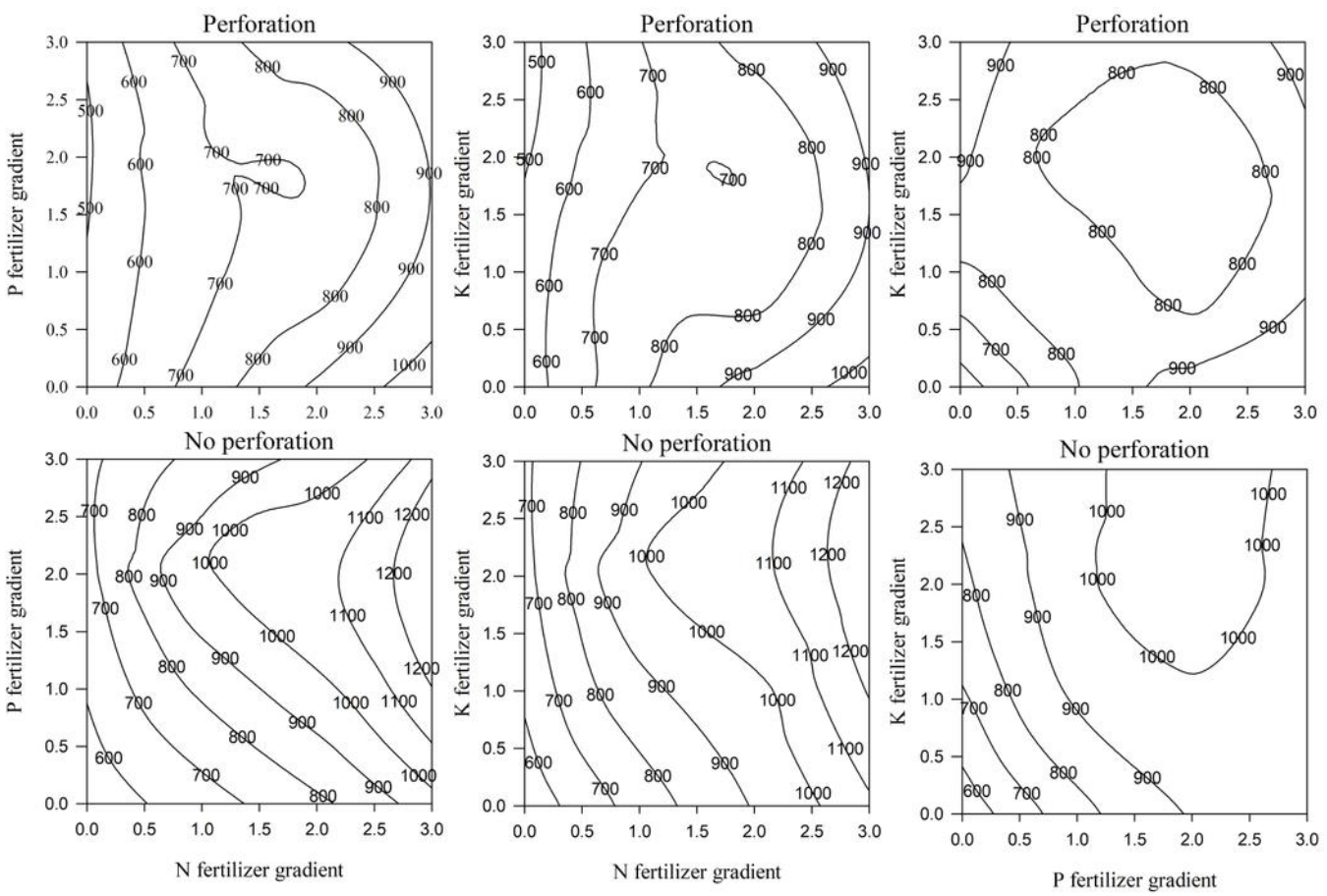

Figure 5. Binary fertilizer effect on the plant community biomass from 2014 to 2017

\section{The effect of total-fertilizer}

A significance test of the regression model showed that the probabilities were: $\mathrm{P}=0.07$ and $\mathrm{P}=0.02$ in perforated and non-perforated plots respectively (Table 2). The actual circumstances are reflected primarily by the regression model, with a liner positive correlation coefficient $\left(\mathrm{R}^{2}\right)$ between theoretical biomass $(\mathrm{Y})$ and objective biomass (y) of 0.9160 and 0.9578 in perforated and non-perforated plots, respectively. 
This is a highly significant fit between theoretical and objective biomass. The full information model met pre-set conditions for further analysis.

Table 2. Parameter test of full information model

\begin{tabular}{c|c|c|c|c|c|c}
\hline Physical treatment & Index & DF & SS & R-square & F & P > F \\
\hline \multirow{5}{*}{ Perforation } & Linear & 3 & 1861.85 & 0.7857 & 12.48 & 0.02 \\
& Quadratic & 3 & 192.08 & 0.0811 & 1.29 & 0.39 \\
& Cross product & 3 & 116.62 & 0.0492 & 0.78 & 0.56 \\
& Total model & 9 & 2170.56 & 0.9160 & 4.85 & 0.07 \\
\hline \multirow{5}{*}{ No perforation } & Linear & 3 & 3581.79 & 0.8284 & 26.18 & 0.00 \\
& Quadratic & 3 & 364.37 & 0.08431 & 2.66 & 0.18 \\
& Cross product & 3 & 195.19 & 0.0451 & 1.43 & 0.36 \\
& Total model & 9 & 4141.35 & 0.9578 & 10.09 & 0.02 \\
\hline
\end{tabular}

The regression coefficient was analyzed by $t$-test, showing the mono-factor coefficient and reciprocal factors were not significant except $\mathrm{X} 2 * \mathrm{X} 2$ in the nonperforated (Table 3). The $t$-test showed that the combined effects of nitrogen, phosphorous and potassium had non-significant regularity on biomass.

Table 3. Results of model parameter estimation and significance test

\begin{tabular}{c|c|c|c|c|c|c}
\hline Physical treatment & Parameter & DF & Estimate & SE & T & Pr > |t $\mid$ \\
\hline \multirow{5}{*}{ Perforation } & Intercept & 1 & 55.85 & 7.02 & 7.96 & 0.00 \\
& $\mathrm{X} 1$ & 1 & 23.31 & 14.18 & 1.64 & 0.18 \\
& $\mathrm{X} 2$ & 1 & -3.34 & 14.18 & -0.24 & 0.83 \\
& $\mathrm{X} 3$ & 1 & -12.22 & 14.18 & -0.86 & 0.44 \\
& $\mathrm{X} 1 * \mathrm{X} 1$ & 1 & -1.35 & 2.83 & -0.48 & 0.66 \\
& $\mathrm{X} 2 * \mathrm{X} 1$ & 1 & -4.37 & 6.42 & -0.68 & 0.53 \\
& $\mathrm{X} 2 * \mathrm{X} 2$ & 1 & 5.01 & 2.83 & 1.77 & 0.15 \\
& $\mathrm{X} 3 * \mathrm{X} 1$ & 1 & 0.67 & 6.42 & 0.1 & 0.92 \\
& $\mathrm{X} 3 * \mathrm{X} 2$ & 1 & -2.45 & 6.42 & -0.38 & 0.72 \\
& $\mathrm{X} 3 * \mathrm{X} 3$ & 1 & 4.14 & 2.83 & 1.46 & 0.22 \\
\hline \multirow{5}{*}{ No perforation } & $\mathrm{Intercept}$ & 1 & 52.63 & 6.72 & 7.83 & 0.00 \\
& $\mathrm{X} 1$ & 1 & -1.84 & 13.58 & -0.14 & 0.90 \\
& $\mathrm{X} 2$ & 1 & 30.81 & 13.58 & 2.27 & 0.09 \\
& $\mathrm{X} 3$ & 1 & 5.34 & 13.58 & 0.39 & 0.71 \\
& $\mathrm{X} 1 * \mathrm{X} 1$ & 1 & 0.64 & 2.71 & 0.24 & 0.82 \\
& $\mathrm{X} 2 * \mathrm{X} 1$ & 1 & 2.7 & 6.14 & 0.44 & 0.68 \\
& $\mathrm{X} 2 * \mathrm{X} 2$ & 1 & -8.76 & 2.71 & -3.23 & $\mathbf{0 . 0 3}$ \\
& $\mathrm{X} 3 * \mathrm{X} 1$ & 1 & 6.76 & 6.14 & 1.1 & 0.33 \\
& $\mathrm{X} 3 * \mathrm{X} 2$ & 1 & -1.81 & 6.14 & -0.29 & 0.78 \\
& $\mathrm{X} 3 * \mathrm{X} 3$ & 1 & -3.25 & 2.71 & -1.2 & 0.30 \\
\hline \multirow{5}{*}{} & & & & & &
\end{tabular}




\section{The simulated optimization and optimal theoretical regression model}

The highest biomass in the perforated plots was $93.48 \mathrm{~kg} \mathrm{ha}^{-1}$, while it was $129.25 \mathrm{~kg} \mathrm{ha}^{-1}$ in the non-perforated plots. The number of samples that were greater than the maximum value were 549 and 19 in perforated plots and non-perforated plots respectively. The recalculated sample data, the resulting coded value and its optimal fertilization amount and maximum biomass are shown in Table 4. The biomass variable amplitude in the perforated plots was $99.16-99.98 \mathrm{~kg} \mathrm{ha}^{-1}$ with the variation range $\mathrm{N}$ (231.50-238.82 kg ha $\left.{ }^{-1}\right), \mathrm{P}\left(187.25-218.75 \mathrm{~kg} \mathrm{ha}^{-1}\right)$, and $\mathrm{K}\left(28.28-33.32 \mathrm{~kg} \mathrm{ha}^{-1}\right)$, while the variable amplitude of biomass in the non-perforated plots was $130.31-131.21 \mathrm{~kg} \mathrm{ha}^{-1}$ with the variation range $\mathrm{N}\left(274.00-274.00 \mathrm{~kg} \mathrm{ha}^{-1}\right), \mathrm{P}\left(311.50-358.75 \mathrm{~kg} \mathrm{ha}^{-1}\right)$, and $\mathrm{K}$ (75.37-81.03 $\mathrm{kg} \mathrm{ha}^{-1}$ ). Compared with the perforated plots, a higher theoretical biomass and fertilization amount could be obtained in the non-perforated plots.

Table 4. Perforation effect on statistical parameters of simulation optimization of optimal theoretical regression model

\begin{tabular}{c|c|c|c|c|c}
\hline $\begin{array}{c}\text { Physical } \\
\text { treatment }\end{array}$ & Parameter & Nitrogen & Phosphorus & Potassium & Biomass \\
\hline \multirow{4}{*}{ Perforation } & Mean & 2.57 & 1.16 & 1.1 & 99.57 \\
& Standard error & 0.02 & 0.05 & 0.05 & 0.21 \\
& Coding interval (95\%) & $2.53 \sim 2.61$ & $1.07 \sim 1.25$ & $1.01 \sim 1.19$ & - \\
& Actual interval (95\%) & $231.50 \sim 238.82$ & $187.25 \sim 218.75$ & $28.28 \sim 33.32$ & $99.16 \sim 99.98$ \\
\hline \multirow{5}{*}{ No perforation } & Mean & 3 & 1.92 & 2.76 & 130.76 \\
& Standard error & 0 & 0.07 & 0.05 & 0.23 \\
& Coding interval (95\%) & $3.00 \sim 3.00$ & $1.78 \sim 2.05$ & $2.66 \sim 2.86$ & - \\
& Actual interval (95\%) & $274.00 \sim 274.00$ & $311.50 \sim 358.75$ & $75.37 \sim 81.03$ & $130.31 \sim 131.21$ \\
\hline
\end{tabular}

\section{The optimal theoretical regression model}

We used a gradual regression analysis for the full information model in the perforated- and non-perforated plots respectively and chose the coefficients that had significant effects on the biomass (Table 5). The effects of $\mathrm{N}$ were all significant in perforated and non-perforated plots $(\mathrm{P}<0.05)$. The interaction between $\mathrm{P}$ and $\mathrm{K}$ was significant in the non-perforated area $\left(P<0.05, R^{2}=0.12\right)$, which was lower than the effect of nitrogen $\left(\mathrm{P}<0.05, \mathrm{R}^{2}=0.6977\right)$, and the combined effect reached $81.61 \%$. The effects of nitrogen $(\mathrm{N})$, dummy variables $(\mathrm{B})$ and phosphate $(\mathrm{P})$ on the biomass reached $57.71 \%, 18.50 \%$ and $2.03 \%$, respectively.

\section{The effects of optimal concentration of fertilizers on plant diversity}

By optimal theoretical regression model, we got optimal fertilization level and analyzed the Richness and Shannon-Wiener diversity index with corresponding plots in 2014-2017 (Fig. 6). Our results showed that plant diversity responded differently to different years. As the fertilization period increased, whichever fertilizers and whether perforated or not, the values of the Shannon-Wiener index decreased. These changes were more evident in 2017, which was in the fourth year of fertilization. The ShannonWiener index decreased by $44.82-71.94 \%$ compared with 2014 in the perforated and non-perforated plots. The change for four years' species richness in the perforated plots 
was regular, and it was shown decreased gradually every year. Although the change in the non-perforated plots was irregular, whichever fertilizer, decreased obviously in 2017 compare to 2014.

Table 5. The optimal theoretical regression model

\begin{tabular}{c|c|c|c|c|c|c|c|c|c}
\hline $\begin{array}{c}\text { Treatments of } \\
\text { perforation }\end{array}$ & $\begin{array}{c}\text { Variable } \\
\text { entered }\end{array}$ & Estimate & $\begin{array}{c}\text { Number } \\
\text { Vars In }\end{array}$ & Partial R-Square & Model R-Square & $\mathbf{C}(\mathbf{p})$ & $\mathbf{F}$ & Pr $>\mathbf{F}$ & $\begin{array}{c}\text { Model } \\
\text { Pr }>\mathbf{F}\end{array}$ \\
\hline \multirow{5}{*}{ Total } & Intercept & 47.81 & & & & & & 109.71 & $<.0001$ \\
& $\mathrm{X} 1$ & 15.06 & 1 & 0.5771 & 0.5771 & 10.61 & 35.47 & $<.0001$ & \\
& $\mathrm{~B}$ & 14.73 & 2 & 0.1850 & 0.7620 & -2.53 & 19.43 & 0.0002 & $<.0001$ \\
& $\mathrm{X} 2$ & 3.07 & 3 & 0.0203 & 0.7823 & -2.19 & 2.23 & 0.1480 & \\
\hline \multirow{2}{*}{ Perforation } & Intercept & 54.60 & & & & & 188.46 & $<.0001$ & $<.0001$ \\
& $\mathrm{X} 1$ & 13.82 & 1 & 0.7597 & 0.7597 & 1.45 & 37.94 & $<.0001$ & \\
\hline \multirow{3}{*}{ No perforation } & Intercept & 56.75 & & & & & 109.24 & $<.0001$ & \\
& $\mathrm{X} 1$ & 16.62 & 1 & 0.6977 & 0.6977 & 18.66 & 27.70 & 0.0002 & $<.0001$ \\
& $\mathrm{X} 2 * \mathrm{X} 3$ & 3.09 & 2 & 0.1184 & 0.8161 & 9.44 & 7.08 & 0.0222 & \\
\hline
\end{tabular}

$\mathrm{R}$-Square represents coefficient of determination. Variable B was dummy variable which combined the data of perforated- and non-perforated plots to perform a new regression analysis with fertilization
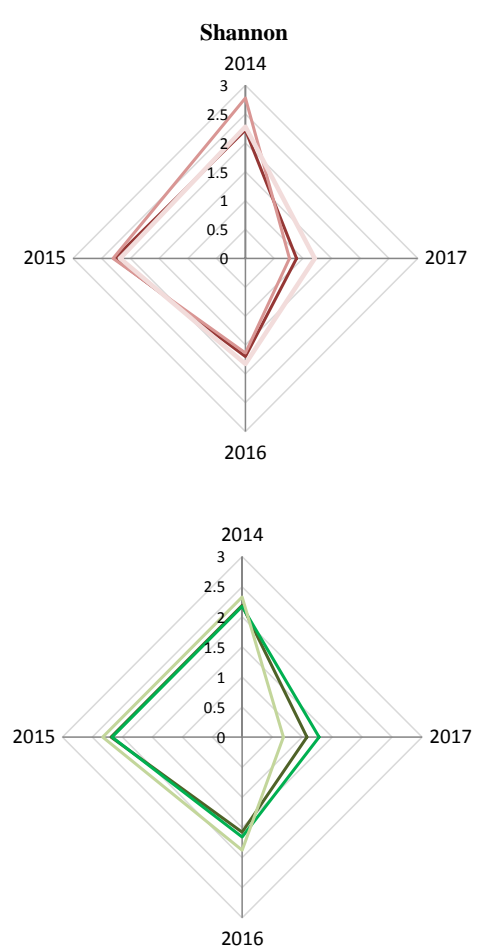
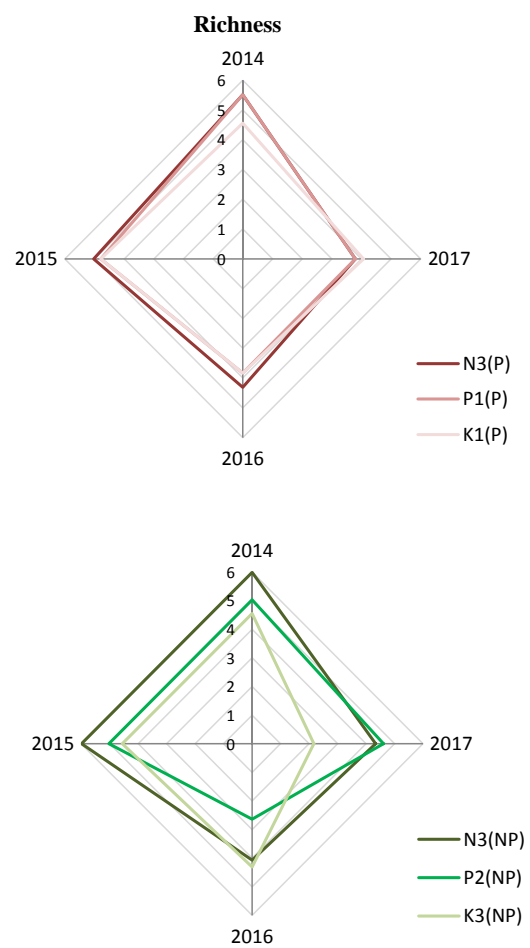

Figure 6. Radar charts showing Shannon-Wiener Index and Species richness, which were the suitable fertilizer level in Table 4. N, P and $K$ represent nitrogen fertilizer, phosphate fertilizer and potash respectively. The letters ' $P$ ' and ' $N P$ ' in brackets represent the samples in the perforated and non-perforated plots

\section{Discussion}

\section{The biomass responses to mono-fertilizer}

The positive effect of $\mathrm{N}$ fertilizer on biomass yield in this study is consistent with other fertilization research on mixed-species grasslands (Boyer et al., 2012; Haque et 
al., 2009; Lee et al., 2013). In our study, the significant effect of $\mathrm{N}$ existed in both perforated and non-perforated plots. The biomass consistently rising with increased $\mathrm{N}$ on Hulunbuir grassland was differed from other studies (Lee et al., 2013). This may have been due to a number of environmental changes beyond the control of this project such as annual rainfall and the perforated treatment. Many previous studies have observed these divergent effects of fertilizer addition are mediated by many factors which vary in time and space, including but not limited to fertilizer dosage, the traits of the species composing the community, soil moisture and climate (Heggenstaller et al., 2009; Kang et al., 2013; Ma et al., 2008). Irrespective of rainfall availability from 2014 to 2017, the biomass increased significantly as fertilizer concentration increased. This result is unexpected. Drought is usually the reason for the biomass of high-diversity communities having a strong reduction, or the reduction of species or plant functional groups that are sensitive to drought, such as legumes (Pfisterer and Schmid, 2002). Contrary to our hypothesis, average yield was lower from 2014 to 2017 in the perforated plots compared to the non-perforated plots-possibly due to the variation in the rate of the fertilizers or drought which affected the biomass response to fertilizer. However, it was not possible to identify the mechanism responsible for the changing response factors. In the perforated plots, $\mathrm{P}$ and $\mathrm{K}$ harvest were lower compared to the reported values in the non-perforated plots. Unlike $\mathrm{N}, \mathrm{P}$ and $\mathrm{K}$ saturated at medium fertilization concentration in the non-perforated plots. However, there is a threshold grassland productivity response to fertilization (Kidd et al., 2017; Silvertown, 1980). This may also include a failure to detect beyond critical environmental thresholds. The inconsistencies are likely to exist due to the differences between the designs of grassland experiments, while the magnitude of fertilization effects may differ depending on the length of the experiment (Kidd et al., 2017).

\section{The interaction of nitrogen, phosphorus and potassium fertilizer on biomass}

Long-term grassland management practices of adding NPK, which could be considered a disturbance on above- and below-ground community compositions, intended to increase vegetation productivity affect the composition and diversity of the plant community (Cassman et al., 2016; Leff et al., 2015; Pickett et al., 1989). Nitrogen may enhance plant acquisition of $\mathrm{P}$ in a number of ways (Bobbink et al., 1998; Long et al., 2016; Lü et al., 2012; Pardo et al., 2007; Sardans and Peñuelas, 2012). For example, the effects of $\mathrm{P}$ on plant nutrition may be regulated by $\mathrm{N}$ addition due to the synergistic interaction between $\mathrm{N}$ and $\mathrm{P}$ in plant metabolism (Güsewell, 2004; Niklas et al., 2005). However, we did not find significant NP interaction in our study while the interaction effects of NK and PK were larger in the perforated plots. We supposed that (1) P and K addition alone would not achieve the effect of our experiment because Inner Mongolia grasslands are mainly $\mathrm{N}$ limited (Bai et al., 2010), and (2) the interaction of PK would be enhanced because of the positive effect of $\mathrm{N}$ addition on plant $\mathrm{P}$ and $\mathrm{K}$ uptake, and (3) compared to non-perforated plots, the plants in perforated plots may have benefited from improved nutrient uptake.

\section{Effects of aeration}

Most studies of grassland aeration have concentrated on forage production with mixed results. Aeration has been found to increase, decrease, or have no effect on forage production (Chapman et al., 2000; Taylor et al., 1983; Gordon et al., 2000; Malhi 
et al., 2000). The perforated plots in our study seemed to need a slightly lower nutrients than the non-perforated plots but increased biomass was found in the non-perforated plots. We might ignore the plants that might have been killed as a result of the mechanical operation, resulting in the biomass in the perforated plots being lower. From an economic point of view, it is more conducive to increase profits by fertilizing only the native grassland without perforating. Studies have shown that the effect of aeration is likely to vary depending on soil hydrological properties and the features may be indicative as to when aeration may reduce runoff and P losses (Pierson et al., 2001). The lack of our hypothetical effect of aeration on biomass yield may have been caused by the loss of soil moisture from removal of vegetative thatch, as well as the differences in soil characteristics or by other environmental factors such as drought. The area in which this study was conducted was exposed to haying for decades prior to the present study. Thus, the improvement of soil compaction was the expected result may not have occurred because of the limitation of machinery, which would limit the response to aeration (Franklin et al., 2006). On the other hand, the effect of soil aeration appears to be greater than the fertilization effect in our study resulting in lower biomass in the perforated plots. This will be a consideration for future research.

\section{Species richness and Shannon diversity response to fertilizers}

Species richness, Shannon diversity and other dimensions-commonly lead to enhanced productivity through the mechanism of complementarity (Hejcman et al., 2007; Yahdjian et al., 2011). Species losses and declines in species richness per unit area are commonly induced by fertilizer addition. Shannon index decreased to a better extent with fertilization period increased (Bobbink et al., 2010; Kahmen et al., 2002). This is a good illustration of the theory that the longer the fertilization treatments lasted, the lower Shannon diversity became. It suggests that adding fertilizers has the tendency to decrease Shannon diversity, although other factors, such as the addition of NPK, can have interactive effects (Kahmen et al., 2002; Moog et al., 2002). Species richness was obviously negatively change to fertilizer period increased. There are several ecological mechanisms that can drive grassland plant community changes. First, it has been demonstrated that fertilization can negatively impact species richness, which diminishes trade-off opportunities that allow species coexistence (Levine and HilleRisLambers, 2009). Second, the stronger negative effects on plant species richness might be found when $\mathrm{P}$ and $\mathrm{K}$ were jointly added to $\mathrm{N}$ compared to $\mathrm{N}$ alone, it suggested nutrient colimitation fertilization can also increase belowground root competition and cause additional competitive exclusion among species (Dickson and Foster, 2011; Humbert et al., 2016).

\section{Conclusion}

In this study, we have shown the effect of grassland fertilization and soil aeration on plant community biomass in the semi-arid steppe, Northern China. Based on the estimates from the simulated optimization and optimal theoretical regression model, we recommend applying fertilizers with the variation range $\mathrm{N}\left(231.50-238.82 \mathrm{~kg} \mathrm{ha}^{-1}\right)$, and $\mathrm{P}\left(187.25-218.75 \mathrm{~kg} \mathrm{ha}^{-1}\right)$, and $\mathrm{K}\left(28.28-33.32 \mathrm{~kg} \mathrm{ha}^{-1}\right)$, and annually to maximize biomass from the semi-arid grassland in Hulunbuir Inner Mongolia, China. Plant community biomass increases following $\mathrm{N}$ addition appear to be a universal pattern across grassland systems. Here, we further establish that effects on plant community 
biomass are negatively and additively influenced by the dose of $\mathrm{N}$ applied and duration of application, as well as the lower Shannon diversity and Species richness became as the longer the fertilization treatments lasted. In our study, the effectiveness of soil aeration appears to be greater than the fertilization effect and it will be a consideration for future research. We therefore conclude that short-term studies are unlikely to possess the required timeframe to accurately predict long-term responses, requiring long-term experiments to explain the effectiveness of aeration on biomass of grassland community in Inner Mongolian Steppe. In future experiment, water control will be carried out the original design, to simulate the impact of different precipitation on the experimental results of this study.

Acknowledgements. This study was supported by National public welfare industry (agriculture) research project (No. 2013060), National Key Project (No. 2016YFC0500603), Inner Mongolia Key Lab of Grassland Management and Utilization, and Innovative Team of Grassland Resources from the Ministry of Education of China (IRT_17R59). We gratefully acknowledge the technical support of the staff of the Hulunbuir Grassland Ecosystem National Field Observation Station. Special thanks go to Jingzhong Dai and Jing Yao for support during the data collection and regular management of the experimental plots.

\section{REFERENCES}

[1] Agren, G. I., Wetterstedt, J. A., Billberger, M. F. (2012): Nutrient limitation on terrestrial plant growth-modeling the interaction between nitrogen and phosphorus. - New Phytol 194: 953-960.

[2] Aguiar, M. R., Paruelo, J. M., Sala, O. E., Lauenroth, W. K. (1996): Ecosystem responses to changes in plant functional type composition: an example from the Patagonian steppe. - Journal of Vegetation Science 7: 381-390.

[3] Bai, Y., Wu, J., Clark, C. M., Naeem, S., Pan, Q., Huang, J. (2010): Tradeoffs and thresholds in the effects of nitrogen addition on biodiversity and ecosystem functioning: evidence from inner Mongolia Grasslands. - Global Change Biology 16: 358-372.

[4] Bardgett, R. D., Wardle, D. A., Yeates, G. W. (1998): Linking above-ground and belowground interactions: how plant responses to foliar herbivory influence soil organisms. Soil Biology and Biochemistry 30: 1867-1878.

[5] Bassin, S., Volk, M., Suter, M., Buchmann, N., Fuhrer, J. (2007): Nitrogen deposition but not ozone affects productivity and community composition of subalpine grassland after 3 yr of treatment. - New Phytologist 175: 523-534.

[6] Basso, B., Dumont, B., Cammarano, D., Pezzuolo, A., Marinello, F., Sartori, L. (2016): Environmental and economic benefits of variable rate nitrogen fertilization in a nitrate vulnerable zone. - Science of The Total Environment 545-546: 227-235.

[7] Bobbink, R., Hornung, M., Roelofs, J. G. M. (1998): The effects of air-borne nitrogen pollutants on species diversity in natural and semi-natural European vegetation. - Journal of Ecology 86: 717-738.

[8] Bobbink, R., Hicks, K., Galloway, J., Spranger, T., Alkemade, R., Ashmore, M. (2010): Global assessment of nitrogen deposition effects on terrestrial plant diversity: a synthesis. - Ecological Applications 20: 30-59.

[9] Boyer, C. N., Tyler, D. D., Roberts, R. K., English, B. C., Larson, J. A. (2012): Switchgrass yield response functions and profit-maximizing nitrogen rates on four landscapes in Tennessee. - Agronomy Journal 104: 1579-1588.

[10] Cassman, N. A., Leite, M. F. A., Pan, Y., de Hollander, M., van Veen, J. A., Kuramae, E. E. (2016): Plant and soil fungal but not soil bacterial communities are linked in long-term fertilized grassland. - Scientific Reports 6: 23680. 
[11] Chapman, R., Singleton, P. L., Thom, E. R. (2000): Shallow mechanical loosening of a soil under dairy cattle grazing: effects on soil and pasture AU - Burgess, C. P. - New Zealand Journal of Agricultural Research 43: 279-290.

[12] Dickson, T. L., Foster, B. L. (2011): Fertilization decreases plant biodiversity even when light is not limiting. - Ecology Letters 14: 380-388.

[13] Elser, J. J., Bracken, M. E., Cleland, E. E., Gruner, D. S., Harpole, W. S., Hillebrand, H. (2007): Global analysis of nitrogen and phosphorus limitation of primary producers in freshwater, marine and terrestrial ecosystems. - Ecology Letter 10: 1135-1142.

[14] Fay, P. A., Prober, S. M., Harpole, W. S., Knops, J. M. H., Bakker, J. D., Borer, E. T. (2015): Grassland productivity limited by multiple nutrients. - Nature Plants 1: 15080.

[15] Franklin, D. H., Cabrera, M. L., Calvert, V. H. (2006): Fertilizer source and soil aeration effects on runoff volume and quality. - Soil Science Society of America Journal 70. DOI: 10.2136/sssaj2003.0114.

[16] George, T. S., Fransson, A. M., Hammond, J. P., White, P. J. (2006): Phosphorus nutrition: rhizosphere processes, plant response and adaptations. - Phosphorus in Action: 245-271.

[17] Gordon, R., Patterson, G., Harz, T., Rodd, V., MacLeod, J. (2000): Soil aeration for dairy manure spreading on forage: effects on ammonia volatilization and yield. - Canadian Journal of Soil Science 80: 319-326.

[18] Gough, L., Osenberg, C. W., Gross, K. L., Collins, S. L. (2000): Fertilization effects on species density and primary productivity in herbaceous plant communities. - Oikos 89: 428-439.

[19] Güsewell, S. (2004): N: P ratios in terrestrial plants: variation and functional significance. - New Phytologist 164: 243-266.

[20] Han, L., Tsunekawa, A., Tsubo, M. (2011): Effect of frozen ground on dust outbreaks in spring on the eastern Mongolian Plateau. - Geomorphology 129: 412-416.

[21] Haque, M., Epplin, F. M., Taliaferro, C. M. (2009): Nitrogen and harvest frequency effect on yield and cost for four perennial grasses. - Agronomy Journal 101: 1463-1469.

[22] Harrison, A. F. (1983): Relationship between intensity of phosphatase activity and physico-chemical properties in woodland soils. - Soil Biology and Biochemistry 15: 9399.

[23] Heggenstaller, A. H., Moore, K. J., Liebman, M., Anex, R. P. (2009): Nitrogen influences biomass and nutrient partitioning by perennial, warm-season grasses. - Agronomy Journal 101: 1363-1371.

[24] Hejcman, M., Klaudisová, M., Schellberg, J., Honsová, D. (2007): The Rengen grassland experiment: plant species composition after 64 years of fertilizer application. Agriculture, Ecosystems and Environment 122: 259-266.

[25] Hofer, D., Suter, M., Buchmann, N., Lüscher, A. (2017): Nitrogen status of functionally different forage species explains resistance to severe drought and post-drought overcompensation. - Agriculture, Ecosystems and Environment 236: 312-322.

[26] Humbert, J. Y., Dwyer, J. M., Andrey, A., Arlettaz, R. (2016): Impacts of nitrogen addition on plant biodiversity in mountain grasslands depend on dose, application duration and climate: a systematic review. - Global Change Biology 22: 110-120.

[27] John, R., Chen, J., Giannico, V., Park, H., Xiao, J., Shirkey, G. (2018): Grassland canopy cover and aboveground biomass in Mongolia and Inner Mongolia: spatiotemporal estimates and controlling factors. - Remote Sensing of Environment 213: 34-48.

[28] Kahmen, S., Poschlod, P., Schreiber, K. F. (2002): Conservation management of calcareous grasslands. Changes in plant species composition and response of functional traits during 25 years. - Biological Conservation 104: 319-328.

[29] Kang, M., Dai, C., Ji, W., Jiang, Y., Yuan, Z., Chen, H. Y. H. (2013): Biomass and its allocation in relation to temperature, precipitation, and soil nutrients in Inner Mongolia grasslands, China. - PLoS ONE 8: e69561. 
[30] Kayser, M., Müller, J., Isselstein, J. (2018): Grassland renovation has important consequences for C and N cycling and losses. - Food and Energy Security 7: e00146.

[31] Kidd, J., Manning, P., Simkin, J., Peacock, S., Stockdale, E. (2017): Impacts of 120 years of fertilizer addition on a temperate grassland ecosystem. - PLoS ONE 12: e0174632.

[32] Kuzyakov, Y., Kretzschmar, A., Stahr, K. (1999): Contribution of Lolium perenne rhizodeposition to carbon turnover of pasture soil. - Plant and Soil 213: 127-136.

[33] Lambin, E. F., Meyfroidt, P. (2011): Global land use change, economic globalization, and the looming land scarcity. - Proceedings of the National Academy of Sciences 108: 3465.

[34] Lee, D. K., Aberle, E., Chen, C., Egenolf, J., Harmoney, K., Kakani, G. (2013): Nitrogen and harvest management of Conservation Reserve Program (CRP) grassland for sustainable biomass feedstock production. - GCB Bioenergy 5: 6-15.

[35] Leff, J. W., Jones, S. E., Prober, S. M., Barberán, A., Borer, E. T., Firn, J. L. (2015): Consistent responses of soil microbial communities to elevated nutrient inputs in grasslands across the globe. - Proceedings of the National Academy of Sciences 112: 10967-10972.

[36] Levine, J. M., HilleRisLambers, J. (2009): The importance of niches for the maintenance of species diversity. - Nature 461: 254.

[37] Li, L. J., Zeng, D. H., Yu, Z. Y., Fan, Z. P., Mao, R. (2010): Soil microbial properties under $\mathrm{N}$ and $\mathrm{P}$ additions in a semi-arid, sandy grassland. - Biology and Fertility of Soils 46: 653-658.

[38] Liu, Y., Taxipulati, T., Gong, Y., Sui, X., Wang, X., Parent, S. É. (2017): N-P Fertilization inhibits growth of root hemiparasite Pedicularis kansuensis in natural grassland. - Frontiers in Plant Science 8.

[39] Long, M., Wu, H. H., Smith, M. D., La Pierre, K. J., Lü, X. T., Zhang, H. Y. (2016): Nitrogen deposition promotes phosphorus uptake of plants in a semi-arid temperate grassland. - Plant and Soil 408: 475-484.

[40] Lü, X. T., Kong, D. L., Pan, Q. M., Simmons, M. E., Han, X. G. (2012): Nitrogen and water availability interact to affect leaf stoichiometry in a semi-arid grassland. Oecologia 168: 301-310.

[41] Ma, W., Yang, Y., He, J., Zeng, H., Fang, J. (2008): Above- and belowground biomass in relation to environmental factors in temperate grasslands, Inner Mongolia. - Science in China Series C: Life Sciences 51: 263-270.

[42] Malhi, S. S., Heier, K., Nielsen, K., Davies, W. E., Gill, K. S. (2000): Efficacy of pasture rejuvenation through mechanical aeration or $\mathrm{N}$ fertilization. - Canadian Journal of Plant Science 80: 813-815.

[43] Montgomery, D. C., Mastrangelo, C. M. (1991): Some statistical process control methods for autocorrelated data. - Journal of Quality Technology 23(3): 179-193.

[44] Moog, D., Poschlod, P., Kahmen, S., Schreiber, K. F. (2002): Comparison of species composition between different grassland management treatments after 25 years. Applied Vegetation Science 5: 99-106.

[45] Niklas, K. J., Owens, T., Reich, P. B., Cobb, E. D. (2005): Nitrogen/phosphorus leaf stoichiometry and the scaling of plant growth. - Ecology Letters 8: 636-642.

[46] Olde Venterink, H., Kardel, I., Kotowski, W., Peeters, W., Wassen, M. J. (2009): Longterm effects of drainage and hay-removal on nutrient dynamics and limitation in the Biebrza mires, Poland. - Biogeochemistry 93: 235-252.

[47] Pardo, L. H., McNulty, S. G., Boggs, J. L., Duke, S. (2007): Regional patterns in foliar $15 \mathrm{~N}$ across a gradient of nitrogen deposition in the northeastern US. - Environmental Pollution 149: 293-302.

[48] Pfisterer, A. B., Schmid, B. (2002): Diversity-dependent production can decrease the stability of ecosystem functioning. - Nature 416: 84.

[49] Pickett, S. T. A., Kolasa, J., Armesto, J. J., Collins, S. L. (1989): The ecological concept of disturbance and its expression at various hierarchical levels. - Oikos 54: 129-136. 
[50] Pierson, S. T., Cabrera, M. L., Evanylo, G. K., Kuykendall, H. A., Hoveland, C. S., McCann, M. A. (2001): Phosphorus and ammonium concentrations in surface runoff from grasslands fertilized with broiler litter. - Journal of Environmental Quality 30: 1784-1789.

[51] Plassmann, K., Edwards Jones, G., Jones, M. L. M. (2009): The effects of low levels of nitrogen deposition and grazing on dune grassland. - Science of The Total Environment 407: 1391-1404.

[52] Sala, O. E., Biondini, M. E., Lauenroth, W. K. (1988): Bias in estimates of primary production: an analytical solution. - Ecological Modelling 44: 43-55.

[53] Sardans, J., Peñuelas, J. (2012): The role of plants in the effects of global change on nutrient availability and stoichiometry in the plant-soil system. - Plant Physiology 160: 1741-1761.

[54] Schulte, R. P. O., Herlihy, M. (2007): Quantifying responses to phosphorus in Irish grasslands: interactions of soil and fertilizer with yield and P concentration. - European Journal of Agronomy 26: 144-153.

[55] Shannon, C. E., Weaver, W. (1949): The Mathematical Theory of Communication. University of Illinois Press, Urbana, IL.

[56] Silvertown, J. (1980): The dynamics of a grassland ecosystem: botanical equilibrium in the park grass experiment. - Journal of Applied Ecology 17: 491-504.

[57] Taylor, E. W., McMurphy, W. E., McLaughlin, G. L. (1983): Equipment for aerating Bermudagrass pastures. - Transactions of the ASAE 26: 352-0353.

[58] Tilman, D., Reich, P. B., Knops, J., Wedin, D., Mielke, T., Lehman, C. (2001): Diversity and productivity in a long-term grassland experiment. - Science 294: 843.

[59] Turner, B. L., Chudek, J. A., Whitton, B. A., Baxter, R. (2003): Phosphorus composition of upland soils polluted by long-term atmospheric nitrogen deposition. Biogeochemistry 65: 259-274.

[60] Yahdjian, L., Gherardi, L., Sala, O. E. (2011): Nitrogen limitation in arid-sub humid ecosystems: a meta-analysis of fertilization studies. - Journal of Arid Environments 75: 675-680.

[61] Yu, L., Song, X. L., Zhao, J. N., Wang, H., Bai, L., Yang, D. L. (2015): Responses of plant diversity and primary productivity to nutrient addition in a Stipa baicalensis grassland, China. - Journal of Integrative Agriculture 10(14): 2099-2108

[62] Zhang, T. Q., MacKenzie, A. F. (1997): Changes of soil phosphorous fractions under long-term corn monoculture. - Soil Science Society of America Journal 61: 485-493.

[63] Zhou, X., Bowker, M. A., Tao, Y., Wu, L., Zhang, Y. (2018): Chronic nitrogen addition induces a cascade of plant community responses with both seasonal and progressive dynamics. - Science of The Total Environment 626: 99-108. 